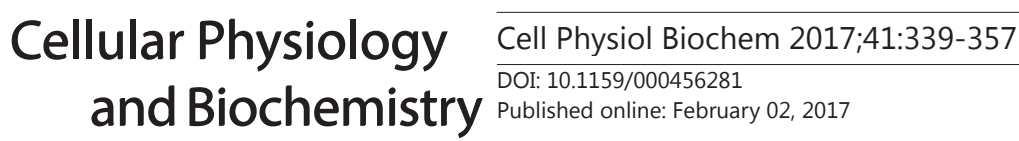

Accepted: December 05, 2016

This article is licensed under the Creative Commons Attribution-NonCommercial-NoDerivatives 4.0 InternaThis article is licensed under the Creative Commons Attribution-NonCommercial-NoDerivatives 4.0 Interna-
tional License (CC BY-NC-ND) (http://www.karger.com/Services/OpenAccessLicense). Usage and distribution tional License (CC BY-NC-ND) (http://www.karger.com/Services/OpenAccessLicense). Usage and dist
for commercial purposes as well as any distribution of modified material requires written permission.

\title{
Emodin Increases Expression of Insulin- Like Growth Factor Binding Protein 1 through Activation of MEK/ERK/AMPK $\alpha$ and Interaction of PPAR $\gamma$ and Sp1 in Lung Cancer
}

\author{
Qing Tang JingJing Wu Fang Zheng YuQing Chen Swei Sunny Hann \\ Department of Medical Oncology, Guangdong Provincial Hospital of Chinese Medicine, The Second \\ Clinical Medical Collage, Guangzhou University of Chinese Medicine, Guangzhou, China
}

\author{
Key Words \\ NSCLC $・$ Emodin $・ P P A R \gamma \cdot I G F B P 1 \cdot S p 1$
}

\begin{abstract}
Background: Emodin has anti-neoplastic activities on multiple tumors. However, the molecular mechanisms underlying this effect still remain to be fully understood. Methods: Cell viability and cell cycle distribution were measured using 3-(4, 5-dimethylthiazol-2-yl)-2, 5-diphenyltetrazolium bromide (MTT) assays and flow cytometry, respectively. Cell invasion and migration were examined by transwell invasion and wound healing assays. Western blot analysis was performed to examine the phosphorylation and protein expression of AMPactivated protein kinase alpha (AMPK $\alpha$ ), extracellular signaling-regulated kinase 1/2 (ERK1/2), peroxisome proliferators-activated receptor gamma (PPAR $\gamma$ ), insulin-like growth factor (IGF) binding protein 1 (IGFBP1) and the transcription factor Sp1. QRT-PCR was used to examine the mRNA levels of the IGFBP1 gene. Small interfering RNAs (siRNAs) were used to knockdown PPAR $\gamma$ and IGFBP1 genes. Exogenously expression of IGFBP1 and Sp1 was determined by transient transfection assays. IGFBP1 promoter activity was measured by Secrete-Pair Dual Luminescence Assay Kit. In vivo nude mice xenograft model and bioluminescent imaging system were used to confirm the findings. Results: We showed that emodin induced cell cycle arrest of NSCLC cells. Emodin increased PPARY protein and luciferase reporter activity, which were abolished by inhibitors of MAPK extracellular signaling-regulated kinase (ERK) kinase (MEK)/ERK and AMPK. Silencing of PPARY abrogated emodin-inhibited cell growth and cell cycle arrest. Furthermore, emodin elevated IGFBP1 mRNA, protein, and promoter activity through activation of PPAR $\gamma$. Intriguingly, overexpressed Sp1 attenuated emodin-induced IGFBP1 expression, which was not observed in cells with silenced PPAR $\gamma$ gene. Moreover, silencing of IGFBP1 gene blunted emodin-induced inhibition of cell growth and cell cycle arrest. On the contrary, overexpressed IGFBP1 enhanced emodin-induced phosphorylation of AMPK $\alpha$ and ERK1/2, and restored emodin-inhibited growth in cells with silenced endogenous IGFBP1 gene. Emodin also inhibited growth of lung xenograft tumors and Sp1, and increased
\end{abstract}




\section{Cellular Physiology Cell Physiol Biochem 2017;41:339-357

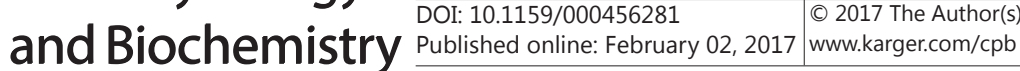

Tang et al.: Emodine Increases IGFBP1 Expression in Human Lung Cancer Cells

IGFBP1 and PPARy protein expressions in vivo. Conclusion: Collectively, our results show that emodin inhibits growth of non-small-cell lung cancer (NSCLC) cells through ERK and AMPK $\alpha$ mediated induction of PPAR $\gamma$, followed by reduction of Sp1. This in turn induces IGFBP1 gene expression. Thus, the signaling cascades, positive feedback loop and cooperative interplay between transcription factors-induced the expression of IGFBP1 gene contribute to the overall responses of emodin. This study provides a novel mechanism by which emodin inhibits growth of human lung cancer cells.

\section{Introduction}

Lung cancer is the leading cause of cancer-related death worldwide and non-smallcell lung cancer (NSCLC) accounts for approximately 80-85\% [1]. Although understand the molecular mechanism and comprehensive treatment have made progress, the 5-year survival rate still remains low, resulting in poor survival $[1,2]$. This further emphasizes the need of novel strategies for the prevention and intervention of this malignancy to improve the overall responses and patient survival.

Peroxisome proliferators-activated receptors (PPARs) are members of the nuclear receptor superfamily of ligand-dependent transcription factors, and heterodimerize with retinoid X receptors (RXRs) upon activation and bind to PPAR response element (PPRE) in the DNA sites of various target genes [3]. Three subtypes have been identified (PPAR $\alpha, \beta$ and $\gamma$ ). Among them, PPAR $\gamma$ plays an important role in the regulation of various biological functions, such as lipid homeostasis, adipogenesis, inflammation, and cancer biology. PPAR $\gamma$ has been shown to be expressed in several types of human malignancies, including lung cancer [4, 5]. Large bodies of evidence have demonstrated anti-proliferative and pro-apoptotic effects of PPAR $\gamma$ agonists suggesting that PPAR $\gamma$ could be considered as a potential target for the treatment of cancers $[6,7]$.

Emodin, a natural anthraquinone derivative isolated from the roots of Rheum palmatuma, exhibited anti-cancer activity through multiple mechanisms in several types of malignancies including lung cancer [8-10]. Consistent with this, we recently found that emodin inhibited growth of NSCLC cells through AMP-activated protein kinase alpha (AMPK $\alpha$ )- and extracellular signaling-regulated kinase (ERK)-mediated inhibition of integrin-linked kinase (ILK) [11]. In addition, one report showed that emodin enhanced chemotherapy-induced cytotoxicity via reducing the expression of excision repair crosscomplementation group 1 (ERCC1) in human lung cancer cells [12]. However, the molecular mechanisms underlying this effect still remain to be fully understood.

The insulin-like growth factor (IGF) binding protein (IGFBP) axis plays critical roles not only in development, metabolism, homeostasis, but also in cell cycle progression, differentiation, apoptosis, and growth in normal and cancer cells [13]. A total of six highaffinity binding proteins have been identified (IGFBP1 to 6) [14]. Among these, IGFBP1, primarily produced by maternal deciduas [15] as well as fetal organs [16], functions in the pericellular and intracellular compartments to regulate cell growth and survival[14]. In addition to their canonical ligands IGF-I and IGF-II, IGFBP1 correlates with other proteins and plays an important role in apoptosis, growth, angiogenesis, tumor-associated lymphangiogenesis, progression and resistance to treatment in several cancer types [14, $17,18]$. Early studies showed that inhibition of IGF receptor 1 function by an excess of IGFBP1 inhibited growth of breast cancer cells [19]. In addition, conjugation of IGFBP1 with polyethylene glycol suppressed tumor growth in athymic mouse models [20]. The stimulation of growth of acute lymphoblastic leukemia cells by IGF-1 can be partially inhibited by IGFBP1 [21]. However, conflicting results also were noticed; especially in prostate cancer type [22, 23]; elevated IGFBP1 appeared to be associated with shorten overall survival with metastatic prostate cancer [23]. Thus, IGFBP1 may have dual effects on cancer cell motility and growth depending upon the content and environment. Data for the link of IGFBP1 and 


\section{Cellular Physiology \\ Cell Physiol Biochem 2017:41:339-357 and Biochemistry

Tang et al.: Emodine Increases IGFBP1 Expression in Human Lung Cancer Cells

lung cancer risk are sparse, whether the expression and function of IGFBP1 in stimulating or inhibiting lung cancer growth and progression remain elusive. Of note, early study found that IGFBP1 gene was one of primary targets of PPARs [24].

In this study, we further explored the potential mechanism by which emodin inhibits growth of NSCLC cells.

\section{Material and Methods}

\section{Reagents and cell cultures}

Monoclonal antibodies specific for total ERK1/2, AMPK $\alpha$ and the phosphor-forms (Thr202/Tyr204, Thr-172), PD98059 were purchased from Cell Signaling Technology Inc. (Beverly, MA, USA). The PPAR $\gamma$, PPAR $\alpha$, Sp1 and IGFBP1 antibodies were obtained from Abcam (Cambridge, MA, USA). MTT powder was purchased from Sigma Aldrich (St. Louis, MO, USA). PPAR $\gamma$ and IGFBP1 small interfering RNAs (siRNAs) and Lipofectamine 3000 reagent were obtained from Life Technologies (AB \& Invitrogen) (Carlsbad, CA, USA). Emodin was purchased from Chengdu Must Bio-technology Company (Chengdu, Sichuan, China). Ciglitazone was obtained from Calbiochem/ Merck Millipore (Billerica, MA, USA). GW9662, compound C and other chemicals were purchased from Sigma Aldrich (St. Louis, MO, USA). All reagents were freshly diluted to the final concentration with culture medium before experiment.

Human lung cancer cells (A549, and H1975) were obtained from the Chinese Academy of Sciences Cell Bank of Type Culture Collection (Shanghai, China) and cultured at $37^{\circ} \mathrm{C}$ in a humidified atmosphere containing 5\% CO2. The culture medium consisted of RPMI 1640 medium from Life Technologies (Carlsbad, CA, USA) supplemented with $10 \%$ (v/v) heat-inactivated fetal bovine serum (Thermo Fisher Scientific Inc, Waltham, MA, USA), $100 \mu \mathrm{g} / \mathrm{ml}$ streptomycin and $100 \mathrm{U} / \mathrm{mL}$ penicillin. In addition, the medium of A549luc was added Geneticin (G-418, Sulfate, Life Technologies, Carlsbad, CA, USA) at concentration of 200 $\mu \mathrm{g} / \mathrm{mL}$. When cells reached $70-80 \%$ confluence, they were digested with $0.25 \%$ trypsin for the following experiments.

\section{Cell viability assay}

Cell viability was measured using the 3-(4, 5-dimethylthiazol-2-yl)-2, 5-diphenyltetrazolium bromide (MTT) assay as reported previously [25]. In brief, NSCLC cells were counted and seeded into a 96-well microtiterplate. The cells $\left(5 \times 10^{3}\right.$ cells/well) were treated with increasing concentrations of emodin for up to $72 \mathrm{~h}$. Afterwards, $10 \mu \mathrm{L}$ MTT solution $\left(5 \mathrm{~g} / \mathrm{L}\right.$ ) was added and incubated at $37^{\circ} \mathrm{C}$ for an additional $3 \mathrm{~h}$. After removing supernatant, $150 \mu \mathrm{L}$ solvent dimethyl sulfoxide (DMSO) was added and oscillated for 5-10 min. Finally, optimal density was determined at $490 \mathrm{~nm}$ absorbance using a spectrophotometer (Perkin Elmer, Victor X5, Waltham, MA, USA). Cell viability was calculated as (absorbance of test sample/absorbance of control).

\section{Cell cycle analysis}

This procedure was reported previously [26]. In brief, A549 cells were cultured in 6-well culture plates at $3 \times 10^{5}$ cells/well and treated with increased doses of emodin for $24 \mathrm{~h}$ or exposed to PPAR $\gamma$ or IGFBP1 siRNA, control one for $24 \mathrm{~h}$ before treated with emodin for an additional $24 \mathrm{~h}$. Afterwards, the cells were washed and resuspended in PBS for $2 \mathrm{~h}$ and incubated in $1 \mathrm{~mL}$ of $0.1 \%$ sodium citrate containing propidium iodide (PI) $0.05 \mathrm{mg}$ and $50 \mu \mathrm{g}$ RNase for $1 \mathrm{~h}$ at room temperature (RT) in dark conditions. The cells were then washed and subjected to FACScalibur flow cytometric analysis (FC500, Beckman Coulter, FL, USA), and the proportion (percentage) of cells within the G0/G1, S, and G2/M phases of the cell cycle were analyzed using the MultiCycle AV DNA Analysis software (Phoenix Flow Systems, USA).

\section{Cell invasion assays}

The in vitro invasive potential of lung cancer cells was assessed by use of the transwell plates with 10 $\mathrm{mm}$ diameter and $8 \mu \mathrm{m}$ pore size polycarbonate membrane (Millipore, USA) coated with Matrigel (Becton, Dickinson and Company, New Jersey, USA) according to instructions. The upper compartment was seeded with $0.5 \times 10^{6}$ A549 cells treated with or without emodin $(50 \mu \mathrm{M}$, in the basal culture medium with $20 \%$ FBS. The lower compartment was filled with the culture medium supplemented with 10\% FBS. After 24 


\section{Cellular Physiology Cell Physiol Biochem 2017;41:339-357 and Biochemistry Publisned online: February 02, 2017 www.karger.com/cpb}

Tang et al.: Emodine Increases IGFBP1 Expression in Human Lung Cancer Cells

h of incubation at $37^{\circ} \mathrm{C}$, cells that had not migrated were removed with a cotton swab; invaded cells were fixed with $4 \%$ paraformaldehyde, and stained with crystal violet. Stained cells were counted in five fields of membrane. Pictures were taken under 100X magnification. Five fields on each membrane were randomly selected and the number of invaded cells was counted as percentage of control.

\section{Wound healing assay}

Changes in migration of cells upon treatment were examined by wound healing assay. In brief, cells $\left(3 \times 10^{5}\right.$ cells $/$ well $)$ were grown as a monolayer in a 6 well plates and a scratch was made on the monolayer. The cells were gently washed and treated with emodin, and maintained in serum free medium. Cell migration into the wound surface was monitored by microscopy for up to $24 \mathrm{~h}$. Images of the scratch were taken at $100 \mathrm{X}$ magnification immediately after addition of emodin. The extent of migration in each sample was photographed by Axiovert 200 microscope (magnification, $\times 100$ ) and measured by Image J software, and expressed as percentage of control $(0 \mathrm{~h})$.

\section{Quantitative real-time PCR}

A quantitative real-time PCR assay was performed for the quantification of IGFBP1 transcripts. The primers used in this study were designed as follows: IGFBP1 forward 5'- TCACAGCAGACAGTGTGAGAC -3'; reverse 5'- CCCAGGGATCCTCTTCCCAT -3'; GAPDH forward 5'-AAGCCTGCCGGTGACTAAC-3'; reverse 5'- GCGCCCAATACGACCAAATC -3'. First-strand cDNA was synthesized from total RNA ( $2 \mu \mathrm{g}$ ) by reverse transcription using oligo-dT primers and superscript II reverse transcriptase (Invitrogen, Grand Island, NY, USA) according to the manufacturer's instructions. Quantitative real-time PCR was performed in a $20 \mu \mathrm{L}$ mixture containing $2 \mu \mathrm{L}$ of the cDNA preparation, $10 \mu \mathrm{L} 2 X$ SYBR Green Premix ExTaq (Takara, Japan), and $10 \mu \mathrm{M}$ primer on an ABI 7500 Real-Time PCR System (Applied Biosystems, Grand Island, NY, USA). The PCR conditions were as follows: $10 \mathrm{~min}$ at $95{ }^{\circ} \mathrm{C}$, followed by 40 cycles of $15 \mathrm{~s}$ at $95^{\circ} \mathrm{C}$, and $1 \mathrm{~min}$ at $60^{\circ} \mathrm{C}$. Each sample was tested in triplicate. Threshold values were determined for each sample/primer pair, the average and standard errors were calculated.

\section{Western blot analysis}

The detailed procedure was reported previously [25]. Briefly, equal amounts of protein from whole cell lysates were separated on SDS polyacrylamide gels. Membranes (Millipore, MA, USA) were incubated with antibodies against phosphor-ERK and AMPK $\alpha$, PPAR $\alpha$, PPAR $\gamma$, IGFBP1 and Sp1 (1:1000). The membranes were washed and incubated with a secondary antibody raised againstrabbit IgG conjugated to horseradish peroxidase (Cell Signaling, Beverly, MA, USA). The membranes were washed again and transferred to freshly made ECL solution (Immobilon Western; Millipore, Billerica, MA, USA), followed by observing signals using the Gel Imagine System (Bio-Rad, Hercules, CA, USA) and documenting the results.

\section{Treatment with PPAR $\gamma$ and IGFBP1 siRNAs}

The detailed procedure was reported previously [25]. For the transfection procedure, cells were seeded in 6-well or 96-well culture plates in RPMI 1640 medium containing 10\% FBS (no antibodies), grown to $60 \%$ confluence, and PPAR $\gamma$, IGFBP1 and control siRNAs purchased from Life Technologies (Carlsbad, CA, USA), were transfected using Lipofectamine 3000 Transfection Reagent. Briefly, Lipofectamine 3000 was incubated with Opti-MEM medium (Invitrogen, Carlsbad, CA, USA) up to $10 \mathrm{~min}$, followed by culturing with siRNA (up to $50 \mathrm{nM}$ ) for an additional $10 \mathrm{~min}$ at room temperature before adding to the cells. After culturing for up to $30 \mathrm{~h}$, the cells were washed and resuspended in fresh media in the presence or absence of emodin for an additional $24 \mathrm{~h}$ for all other experiments.

\section{Transient transfection assays}

The detailed procedure was reported previously [27]. Briefly, NSCLC cells were seeded at a density of $5 \times 10^{5}$ cells/well in 6-well dishes and grown to $50-60 \%$ confluence. For each well, $2 \mu \mathrm{g}$ of the control or PPRE X3-TK-luc reporter construct (obtained from Addgene, Cambridge, MA, USA, plasmid No. 1015) [28], control or wild type pEZX-PG04-IGFBP1 promoter constructs (purchased from GeneCopoeia, Inc., Rockville, MD, USA) with or without $0.2 \mu \mathrm{g}$ of the internal control secreted alkaline phosphatase (SEAP) were cotransfected into the cells with the Lipofectamine 3000. The preparation of cell extracts and measurement of luciferase activities were determined using the Secrete-Pair ${ }^{T M}$ Dual Luminescence Assay Kit (GeneCopoeia, 


\section{Cellular Physiology Cell Physiol Biochem 2017;41:339-357

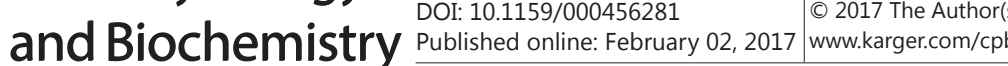

Tang et al.: Emodine Increases IGFBP1 Expression in Human Lung Cancer Cells

Inc., Rockville, MD, USA). Luciferase activity (actual luminescence units) was normalized with SEAP activity within each sample.

\section{Electroporated transfection assays}

The detail procedure was reported previously [25]. NSCLC cells $\left(2 \times 10^{7}\right.$ cells $\left./ \mathrm{mL}\right)$ were transferred into conical tubes and centrifuged at $1200 \mathrm{rpm}$ for $5 \mathrm{~min}$. After centrifuging, medium was removed and the cells were washed with $1 \mathrm{X}$ phosphate buffer saline (PBS), and centrifuged again at $1200 \mathrm{rpm}$ for $5 \mathrm{~min}$. Afterwards, the PBS was aspirated and added Bio-Rad Gene Pulser electroporation buffer. After resuspending the cells, the desired control or IGFBP1 expression vectors (IGFBP1-pCMV6-AC-GFP) purchased from OriGene Technologies, Inc. (Rockville, MD, USA), or control (pcDNA3.1), Sp1 overexpression pcDNA3.1Sp1/ flu vector (kindly provided by Dr. Thomas E. Eling, National Institute of Environmental Health Sciences, USA) [29], at a final concentration of $2 \mu \mathrm{g} / \mathrm{mL}$ were added and the electroporation plate were put in the MX cell plate chamber and closed the lid in Gene Pulser II Electroporation System (Bio-Rad, Hercules, CA, USA). The electroporation conditions on the plates to deliver $148 \mathrm{~V} / 5 \mathrm{~ms}$ square wave were adjusted until reaching the optimum. After electroporation was completed, the cells were transferred to a tissue culture plate. We normally transfer each $150 \mu \mathrm{L}$ electroporation sample to a 6-well tissue culture plate containing $2 \mathrm{~mL}$ RPMI1640. Cells were incubated $48 \mathrm{~h}$ at $37^{\circ} \mathrm{C}$, and then treated with emodin for an additional $24 \mathrm{~h}$.

\section{Xenograft tumors and bioluminescent imaging}

The experiments were performed according to the National Institutes of Health guide for the care and use of Laboratory animals (NIH Publications No. 8023, revised 1978) and approved by the Animal Care and Use Committee of Guangdong Provincial Hospital of Chinese Medicine. A total of 30 eight-week-old female nude mice obtained from Guangdong Provincial Research Center for Laboratory Animal Medicine (Foshan, Guangdong, China) were maintained at the Animal Center of Guangdong Provincial Hospital of Chinese Medicine in a specific pathogen-free environment with food and water provided. A549 NSCLC cells carrying luciferase report gene (A549-Luc, obtained from the Guangzhou Land Technology Co., Guangzhou, China) $\left(1 \times 10^{6}\right.$ cells $)$ in $100 \mu \mathrm{L}$ PBS were injected subcutaneously in the upper hind limb of mice. Xenografts were allowed to grow for over one week when the initial measurement was made with calipers. Mice were randomly divided into control, low $(25 \mathrm{~g} / \mathrm{kg})$ and high doses $(50 \mathrm{~g} / \mathrm{kg})$ of emodin group [30], which given via intraperitoneal injection (once another day) for up to 30 days ( $n=8-10 /$ group).

For bioluminescence imaging (BLI) procedure, mice were anesthetized by inhalation of $2 \%$ isoflurane. The substrate D-luciferin (Caliper Life Sciences, Hopkinton, MA, USA) was injected into the peritoneal cavity with a dose of $150 \mathrm{mg} / \mathrm{kg}$ in approximately $100 \mu \mathrm{L}$. The intensity of BLI signal was determined using the IVIS200 Imaging System (Xenogen/Caliper, Alameda, CA, USA). Tumor volume measurements were calculated using the formula for an oblong sphere: volume $=\left(\right.$ width $^{2} \times$ length $)$. Quantification of bioluminescence (luciferase signal) was reported as photons/sec. The body weights of the mice were measured once a week. All mice were euthanized on day 30 in accordance with the Guide for the Care and Use of Laboratory Animals.

\section{Statistical analysis}

All in vitro experiments were performed at least three times. All data are expressed as mean \pm SD. Differences between groups were assessed by one-way ANOVA and significance of difference between particular treatment groups was analyzed using Dunnett's multiple comparison tests (GraphPadPrism5.0 software, LaJolla, CA). Asterisks showed in the figures indicate significant differences of experimental groups in comparison with the corresponding control one. P-values $<0.05$ were considered statistically significant.

\section{Results}

Emodin induced cell cycle arrest and inhibited invasion and migration in lung cancer cells We previous showed that emodin inhibited growth of human lung cancer cells [11]. In the current study, we further assessed the relative contribution of inhibition affected by emodin using cell cycle assays. As expected, we observed that, compared with the untreated control cells, emodin significantly affected cell cycle distribution, leading to increase the proportion of cells at $\mathrm{G} 2 / \mathrm{M}$ phase in a dose-dependent manner with maximal effect observed 


\section{Cellular Physiology Cell Physiol Biochem 2017;41:339-357

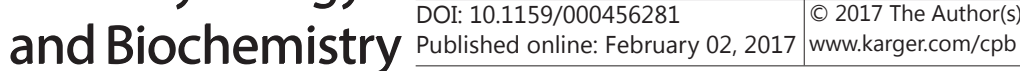

Tang et al.: Emodine Increases IGFBP1 Expression in Human Lung Cancer Cells

at $50 \mu \mathrm{M}$ (Fig. 1A). This result suggested that emodin induced cell cycle arrest in G2/M phase in A549 cells. Moreover, we studied the in vitro invasive properties of lung cancer cells in responding to emodin exposure using matrigel coated transwell inserts. The results indicated that emodin inhibited invasion of A549 cells (Fig. 1B). In addition, as observed by wound healing assay, emodin at $50 \mu \mathrm{M}$ significantly reduced wound closure compared to the untreated control cells indicating reduction of migration in A549 and H1975 cells (Fig. 1C). This result suggested the potential multiple anti-lung cancer effects of emodin.

Emodin increased phosphorylation and protein levels of PPAR $\gamma$, which were abolished by inhibitors of $M E K / E R K$ and $A M P K$

We then set up to examine the effect of emodin on PPAR $\gamma$ expression. We found that emodin $(50 \mu \mathrm{M})$ increased phosphorylation and protein expression of PPAR $\gamma$, while it had no effect on PPAR $\alpha$ protein expression in A549 and H1975 cells (Fig. 2A) suggesting the specificity of targeting PPAR isoforms. Moreover, emodin increased the PPRE-TK luciferase activity (Fig. 2B). Previously, we found that emodin increased the phosphorylation of ERK1/2 and AMPKo signaling pathways in NSCLC cells [11]. Herein, we showed that the inhibitors of MAPK extracellular signaling-regulated kinase (ERK) kinase (MEK)/ERK (PD98059) and AMPK (compound $\mathrm{C}$ ) abrogated the effect of emodin $(50 \mu \mathrm{M}$ ) on PPAR $\gamma$ protein expression in A549 and H1975 cells (Fig. 2C-D). These results suggested that activation of MEK/ERK and AMPK $\alpha$ signaling pathways were required in emodin-induced PPAR $\gamma$ expression.

Emodin inhibited NSCLC cell growth and induced cell cycle arrest through activation of PPARY

We previously demonstrated that emodin inhibited multiple NSCLC cell proliferation as determined by MTT assays [11]. In the current study, we further defined the role of PPAR $\gamma$, we showed that emodin-decreased cell viability and -induced cell cycle arrest were not observed in cells with silenced PPAR $\gamma$ gene by siRNA suggesting that activation PPAR $\gamma$ was required in this process (Fig. 3A-B).

Emodin elevated IGFBPI protein, mRNA and promoter activity, which was abolished by blockade of PPAR $\gamma$

To explore this further, we then tested the PPAR target gene that regulated by emodin. We observed that emodin elevated IGFBP1 protein and mRNA expression, one of PPAR $\gamma$ target genes [24], in A549 and H1975 cells (Fig. 4A-B). As expected, emodin also increased IGFBP1 promoter activity, suggesting a transcriptional regulation of this gene (Fig. 4C). Moreover, blockade of PPAR $\gamma$ activity using antagonist GW9662 and silencing of PPAR $\gamma$ gene by siRNAs abolished the effect of emodin on IGFBP1 promoter activity and protein expression (Fig. 4C and 4D-E). This suggested that activation of PPAR $\gamma$ was required for emodin-induced IGFBP1 expression. Notably, ciglitazone, one synthetic PPAR $\gamma$ ligand, enhanced the effect of emodin on induction of IGFBP1 protein expression in A549 and H1975 cells (Fig. 4F) suggesting a synergistic effect in this process.

Emodin reduced Sp1 protein expression through PPARY; exogenous expression of Sp1 diminished the effect of emodin on IGFBP1 expression

We previously demonstrated that emodin reduced specific transcription factor (Sp1) protein expression in A549 and H1975 NSCLC cells [11]. Importantly, we found that the emodin-inhibited Sp1 expression was abrogated in cells with silenced PPAR $\gamma$ gene (Fig. 5A). This indicated that expression of PPAR $\gamma$ was required in mediating the emodin-reduced Sp1 expression and suggested the role of PPAR $\gamma$ activation in this process. Report showed that IGFBP1 promoter contained Sp1 binding sites and that $\mathrm{Sp} 1$ could regulate IGFBP1 gene expression and its downstream signaling [31]. Interestingly, we showed that exogenously expression of Sp1 transfected into the cells resisted the effect of emodin on IGFBP1 protein expression (Fig. 5B), while it had no effect on expression of PPAR $\gamma$ (Fig. 5B). Intriguingly, the effect of Sp1 expression on IGFBP1 was not observed in cells with silenced PPAR $\gamma$ gene (Fig. 


\section{Cellular Physiology \\ Cell Physiol Biochem 2017;41:339-357 and Biochemistry

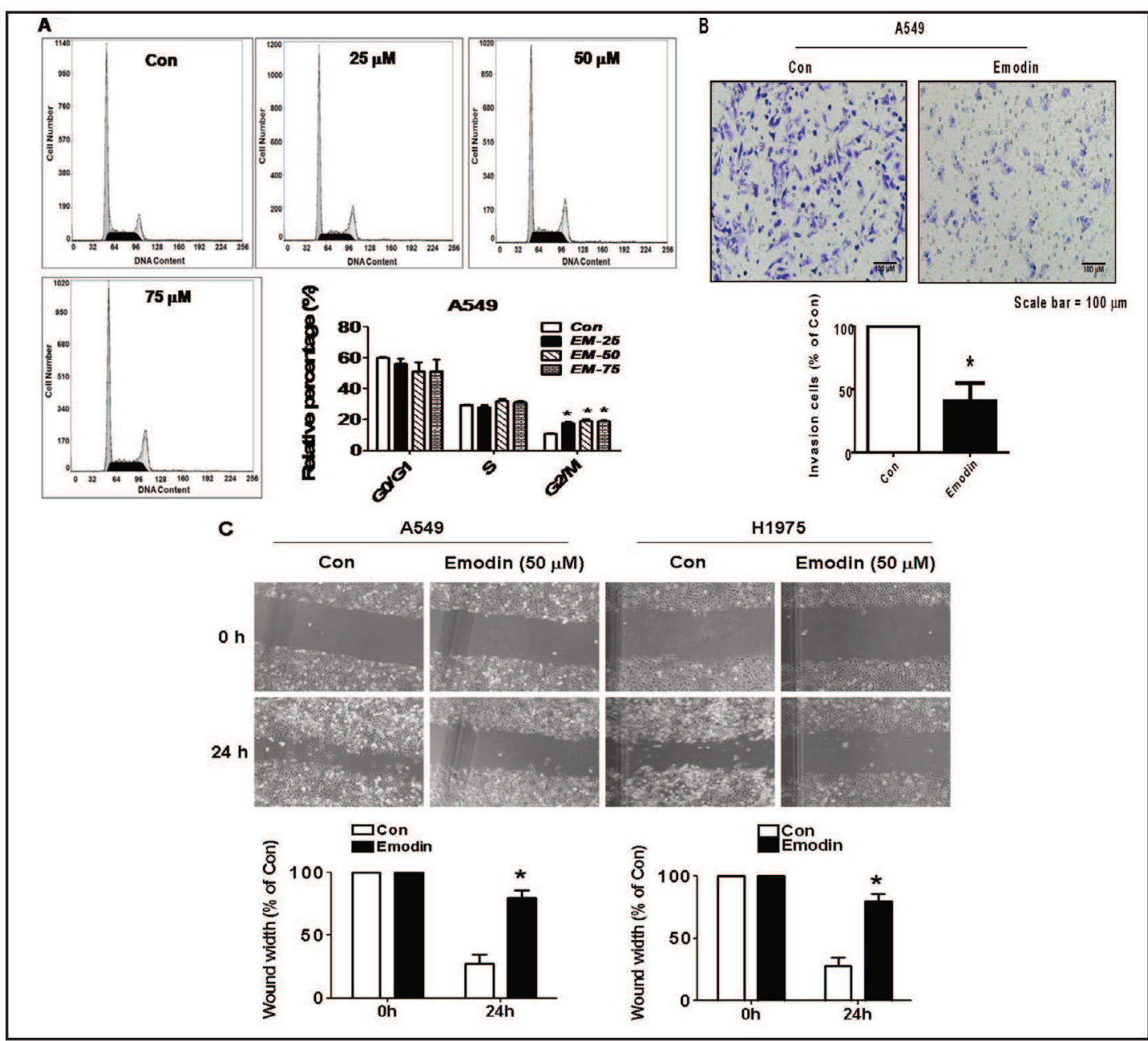

Fig. 1. Emodin induced cell cycle arrest and inhibited migration/invasion of lung cancer cells. A, A549 cells were stimulated with different concentrations of emodin for $24 \mathrm{~h}$. The cells were collected and processed for analysis of cell cycle distribution. Cell cycle was analyzed by flow cytometry after propidium iodide (PI) staining, and the percentages of the cell population in each phase (G0/G1, S and G2/M) of cell cycle were analyzed by Multicycle AV DNA Analysis Software. Data are expressed as a percentage of total cells. Values are given as the mean \pm SD, from 3 independent experiments. *indicates a significant difference from the control group $(\mathrm{P}<0.05)$. B, A549 cells were treated with emodin $(50 \mu \mathrm{M})$ for up to $24 \mathrm{~h}$. Shown are representative images of fixed and crystal violet-stained $\mathrm{A} 549$ cell invasion on the matrigel-coated inserts in the presence of vehicle control (Con), and $50 \mu \mathrm{M}$ emodin. Scale bar $=100 \mu \mathrm{m}$. *indicates a significant difference from the control group $(\mathrm{P}<0.05)$. C, Cell migration ability was determined by scratching confluent A549 and H1975 cell monolayers with a pipette tip. Cells were incubated with emodin $(50 \mu \mathrm{M})$ for $24 \mathrm{~h}$. The extent of migration in each sample was photographed by Axiovert 200 microscope (magnification, $\times 100$ ) and expressed as percentage of control $(0 \mathrm{~h})$. *indicates a significant difference from the control $(0 \mathrm{~h})(P<0.05)$.

5C). Together, the above findings indicated that Sp1, acted as upstream signal of IGFBP1, interacted with PPAR $\gamma$ to regulate the expression of IGFBP1 in NSCLC cells. As expected, ciglitazone increased the effect of emodin on Sp1 protein expression (Fig. 5D).

While silencing of IGFBP1 attenuated, overexpression of IGFBP1 enhanced emodin-

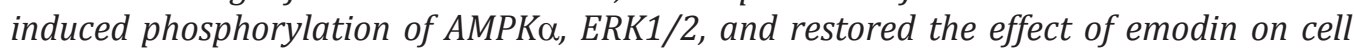
growth inhibition and cell cycle arrest

We further characterized the role of IGFBP1; we found that silencing of IGFBP1 gene antagonized the effect of emodin on not only cell growth inhibition but also induction of 


\section{Cellular Physiology \\ Cell Physiol Biochem 2017;41:339-357 and Biochemistry

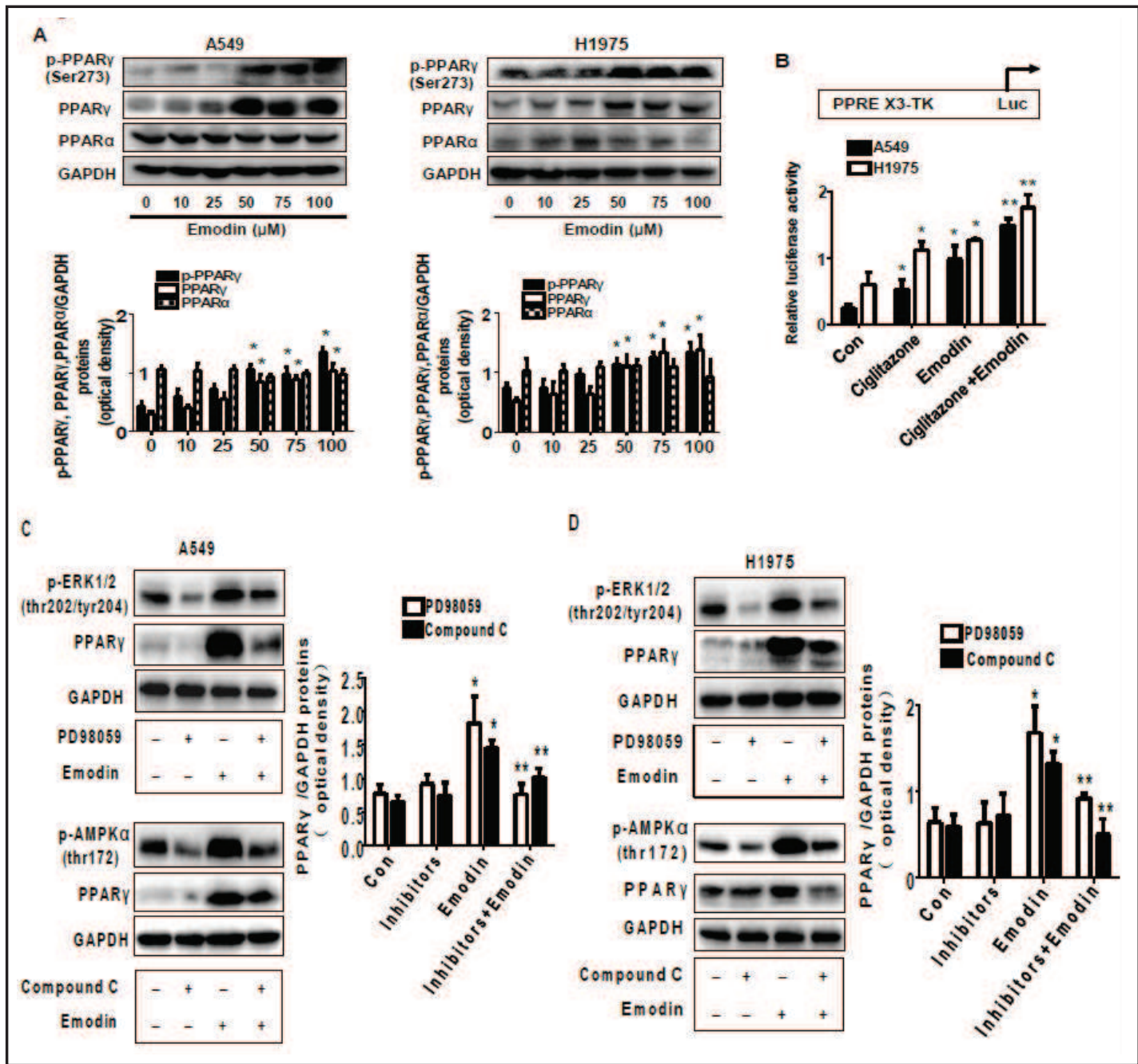

Fig. 2. Emodin increased phosphorylation, protein expression of PPAR $\gamma$, which were abolished by the inhibitors of ERK1/2 and AMPK. A, A549 and H1975 cells were exposed to increased concentration of emodin for $24 \mathrm{~h}$, followed by measuring the phosphorylation and protein expression of PPAR $\gamma$ and PPAR $\alpha$ by Western blot. The bar graphs represent the mean \pm SD of PPAR $\gamma /$ GAPDH of three independent experiments. B, A549 and H1975 cells were transfected with control or PPRE X3-TK-luc reporter for $24 \mathrm{~h}$, followed by treating with emodin $(50 \mu \mathrm{M})$ for an ad additional $24 \mathrm{~h}$. afterwards, the Luciferase reporter activity was measured using Luciferase Assay System according to manufacturer's instructions. C-D, A549 (C) and H1975 (D) cells were treated with PD98059 $(20 \mu \mathrm{M})$ or compound C $(20 \mu \mathrm{M})$ for $2 \mathrm{~h}$ before exposure of the cells to emodin $(50 \mu \mathrm{M})$ for an additional $24 \mathrm{~h}$. Afterwards, phosphorylation of ERK1/2 and AMPK $\alpha$, and expression of PPAR $\gamma$ protein was detected by Western blot. The bars represent the mean \pm SD of at least three independent experiments for each condition. *Indicates significant difference as compared to the untreated control group $(\mathrm{P}<0.05)$; ${ }^{* *}$ Indicates significance of combination treatment as compared with emodin alone $(\mathrm{P}<0.05)$.

cell cycle arrest at G2/M phase (Fig. 6A-B). On the contrary, overexpression of IGFBP1 gene enhanced emodin-induced phosphorylation of AMPK $\alpha$ and ERK1/2 (Fig. 6C). More importantly, it restored the effect of emodin on growth inhibition in cells with silenced endogenous IGFBP1 gene (Fig. 6D). This implied a potential feedback regulatory loop of AMPK $\alpha$ and ERK1/2 by IGFBP1, and also highlighted a tumor suppressor role of IGFBP1. As expected, overexpression of IGFBP1 had no effect on emodin-reduced Sp1 and induced PPAR $\gamma$ protein expression (Fig. 6E). This suggested that activation of PPAR $\gamma$ and inhibition of Sp1 contributed to the emodin-stimulated IGFBP1 expression in this process.

\section{KARGER}




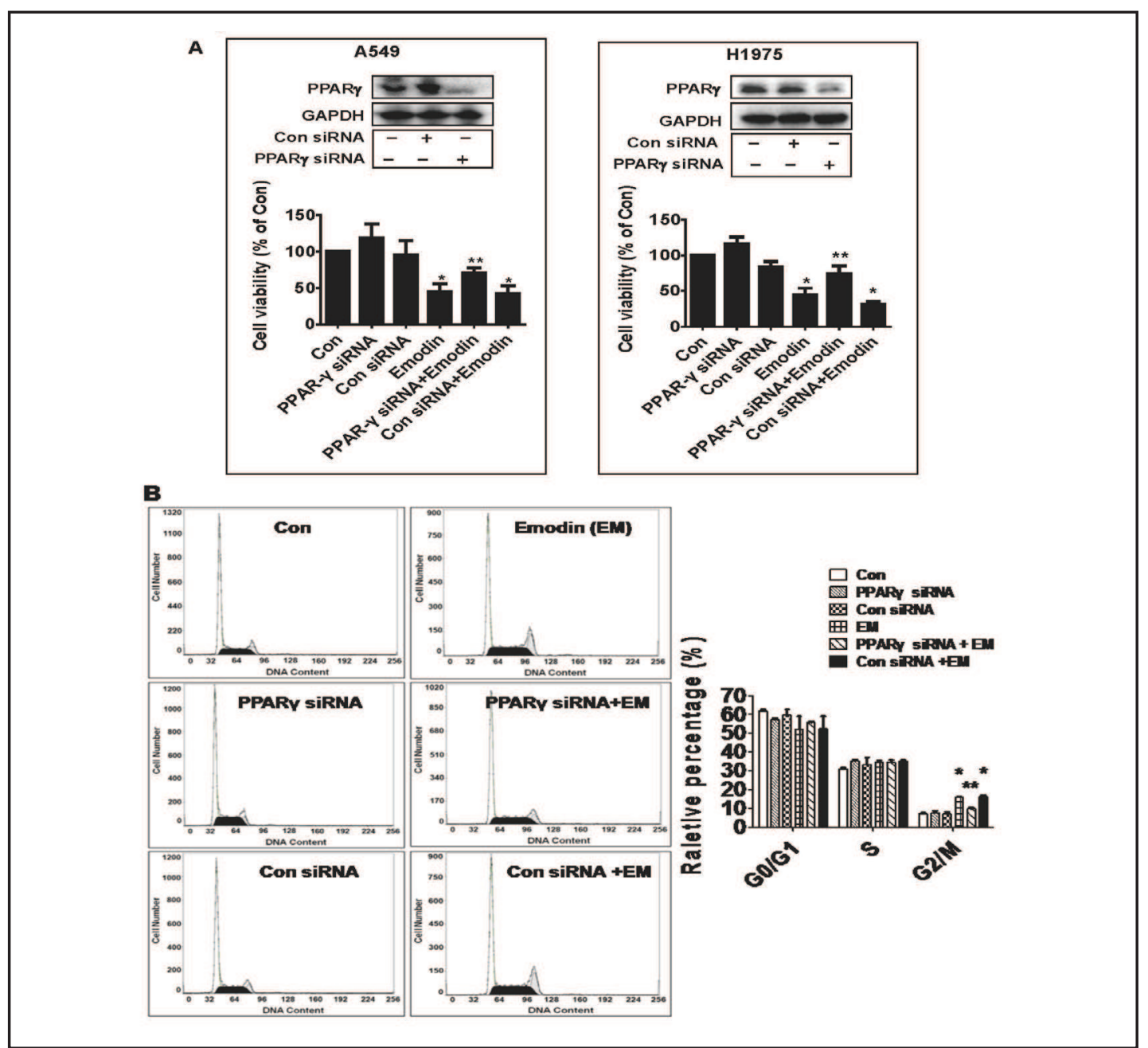

Fig. 3. Emodin inhibited NSCLC cell growth through activation PPAR $\gamma$ signaling pathway. A, Cellular protein was isolated from A549 and H1975 cells transfected with control or PPAR $\gamma$ siRNA for $30 \mathrm{~h}$ before exposure of the cells to emodin $(50 \mu \mathrm{M})$ for an additional $24 \mathrm{~h}$. The cell viability was determined using the MTT assay as described in the Materials and Methods Section and was expressed as percentage of control in the mean \pm SD of three separate experiments. B, A549 cells were transfected control or PPAR $\gamma$ siRNA (50 nM) for up to $30 \mathrm{~h}$ before exposing the cells to emodin $(50 \mu \mathrm{M})$ for an additional $24 \mathrm{~h}$. The cells were collected and processed for analysis of cell cycle distribution. Cell cycle was analyzed by flow cytometry after propidium iodide (PI) staining, and the percentages of the cell population in each phase (G0/G1, S and G2/M) of cell cycle were analyzed by Multicycle AV DNA Analysis Software. Data are expressed as a percentage of total cells. Values are given as the mean \pm SD, from 3 independent experiments. ${ }^{*}$ Indicates significant difference as compared to the untreated control group $(\mathrm{P}<0.05)$. ${ }^{* *}$ Indicates significance of combination treatment as compared with emodin alone $(\mathrm{P}<0.05)$.

In vivo anti-tumor efficacy of emodin in subcutaneous xenograft models of lung cancer

In order to prove the results in vitro, we tested the effect of emodin lung cancer xenografts in nude mice model. Luciferase-expressing A549 cells were injected subcutaneously in nude mice. Mice bearing xenografted lung tumors were treated with control or emodin [30] via intraperitoneal injection for up to 30 days, followed by intraperitoneal injection of D-luciferin. We showed that, compared to the control group, the high dose $(50 \mathrm{mg} / \mathrm{kg})$ emodin-treated mice demonstrated a significant growth-inhibitory effect as assessed by the Xenogen IVIS200 System (Fig. 7A). In addition, we found a significant reduction of the tumor weight and sizes in the high dose of emodin-treated group as compared to the control group (Fig. 


\section{Cellular Physiology \\ Cell Physiol Biochem 2017;41:339-357 and Biochemistry DOI: 10.1159/000456281 2017 (0) 2017 The Author(s). Published by S. Karger AG, Basel

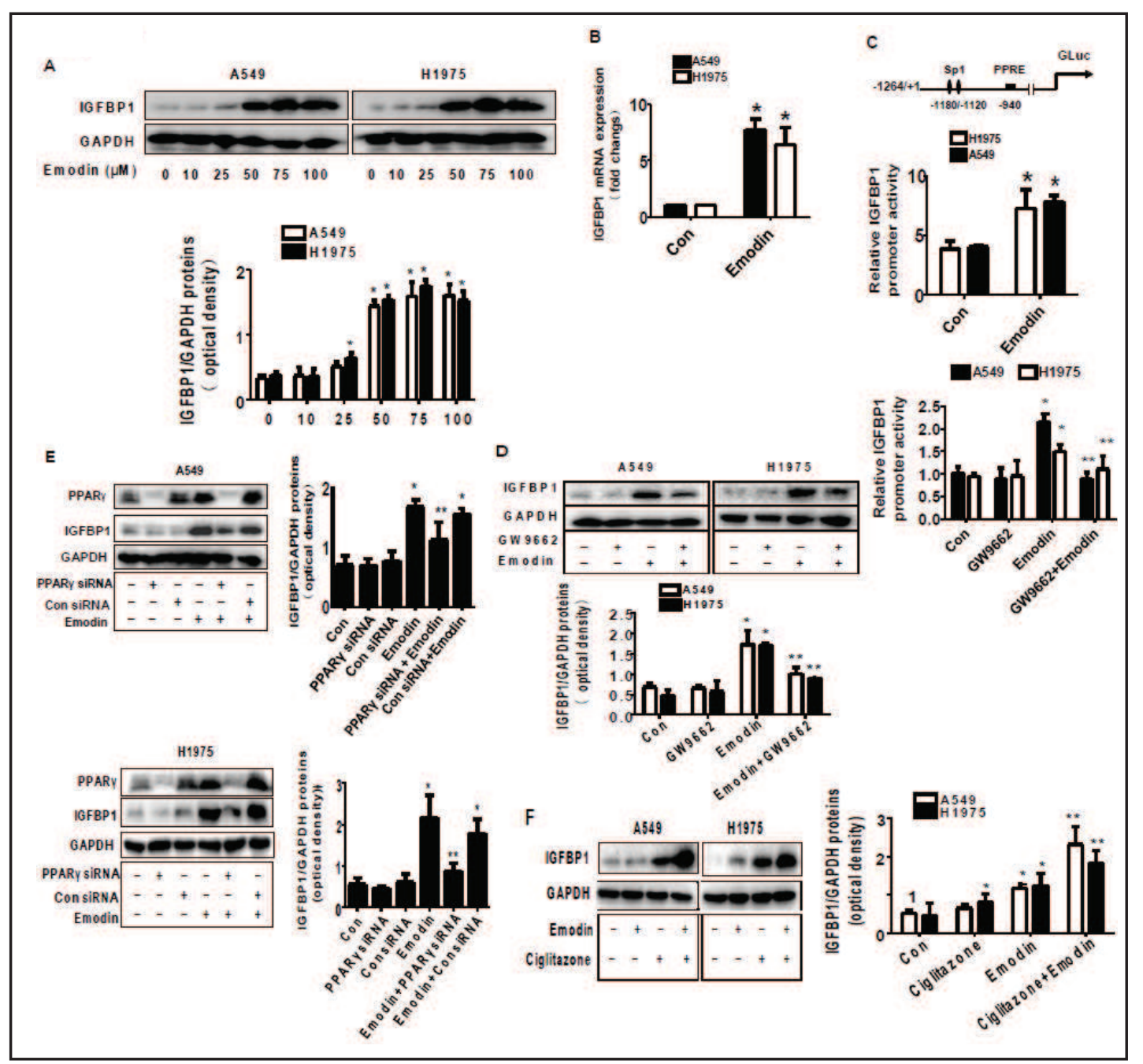

Fig. 4. Emodin elevated IGFBP1 protein, mRNA expression and promoter activity, which was abolished by blockade of PPAR $\gamma$. A-B, A549 and H1975 cells were exposed to increased concentration of emodin or emodin $(50 \mu \mathrm{M})$ for $24 \mathrm{~h}$, followed by measuring the protein and mRNA expressions of IGFBP1 by Western blot and qRT-PCR. C, A549 and H1975 cells were transfected with wild type human IGFBP1 promoter reporter construct ligated to luciferase reporter gene and internal control secreted alkaline phosphatase for $24 \mathrm{~h}$, followed by treating with emodin for an additional $24 \mathrm{~h}$ or GW9662 (20 $\mu \mathrm{M})$ for $2 \mathrm{~h}$ before exposure the cells to emodin for an additional $24 \mathrm{~h}$. Afterwards, the promoter activities were determined using the Secrete-Pair Dual Luminescence Assay Kit as described in the Materials and Methods section. D-E, Cellular protein was isolated from A549 and H1975 cells cultured for $1 \mathrm{~h}$ in the presence or absence of GW9662 (20 $\mu \mathrm{M}$ ) (D) or transfected with control, or PPAR $\gamma$ siRNA (50 nM) (E) for up to $30 \mathrm{~h}$ before exposing the cells to emodin $(50 \mu \mathrm{M})$ for an additional $24 \mathrm{~h}$. Afterwards, the expression of IGFBP1 and PPAR $\gamma$ proteins were detected by Western blot. F, A549 and H1975 cells were exposed to emodin (50 $\mu \mathrm{M})$ and ciglitazone $(30 \mu \mathrm{M})$ for $24 \mathrm{~h}$, followed by measuring the protein expression of IGFBP1 by Western blot. The bar graphs represent the mean \pm SD of IGFBP1/GAPDH of three independent experiments. *Indicates significant difference as compared to the untreated control group $(\mathrm{P}<0.05) ;{ }^{* *}$ Indicates significance of combination treatment as compared with emodin alone $(\mathrm{P}<0.05)$.

7B-C). Moreover, consistent with the results from the in vitro data, the reduced expression of Sp1, whereas increased PPAR $\gamma$ and IGFBP1 proteins from fresh tumors harvested from the aforementioned experiment were observed in the high dose emodin treatment group as compared to that in the control group (Fig. 7D). Note that the low dose of emodin treatment 


\section{Cellular Physiology Cell Physiol Biochem 2017;41:339-357 and Biochemistry

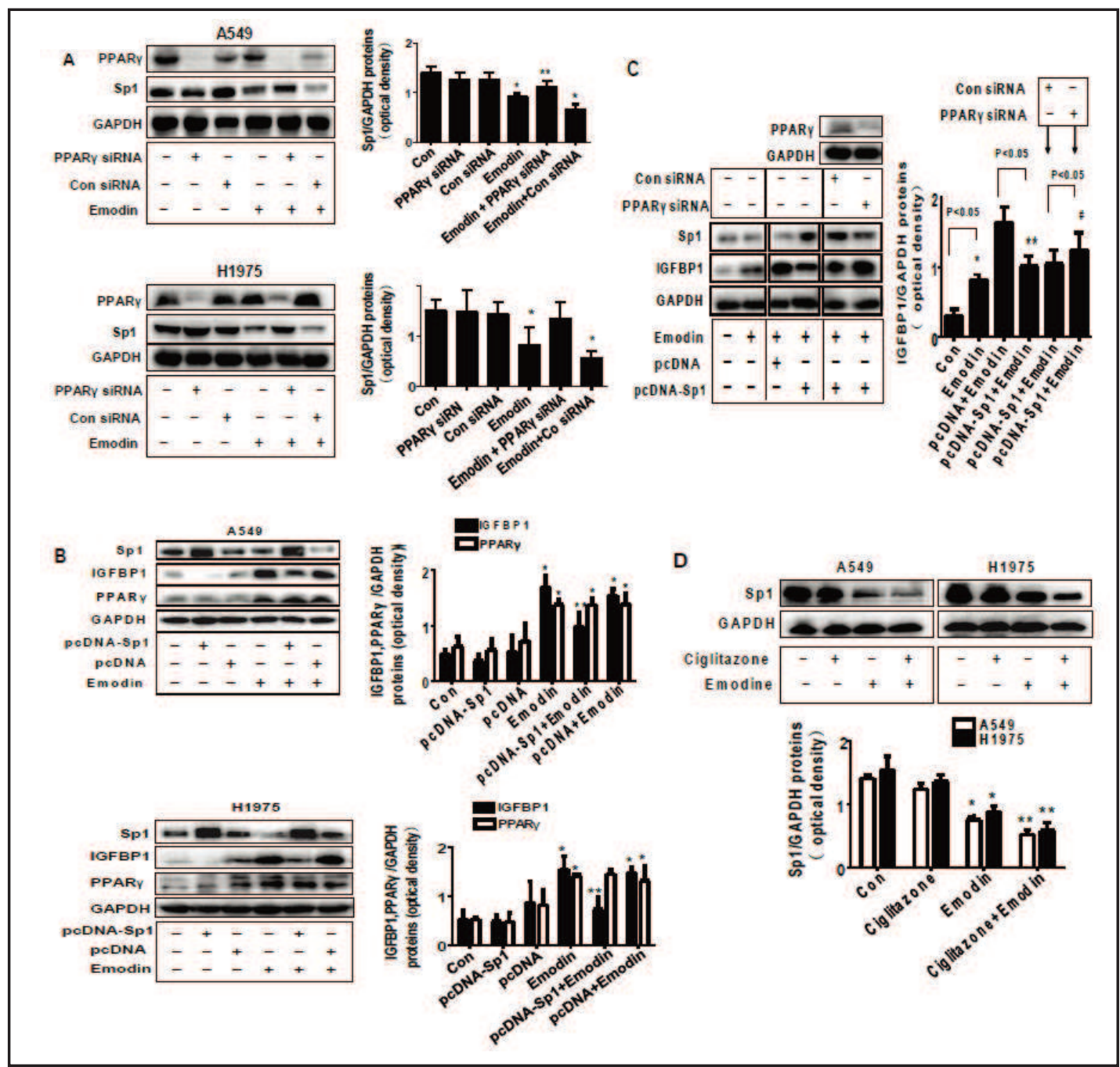

Fig. 5. Silencing of PPAR $\gamma$ overcame emodin-reduced Sp1 protein expression; and antagonized emodin-induced IGFBP1 expression in cells exogenous expression of Sp1. A, Cellular protein was isolated from A549 and H1975 cells transfected with control or PPAR $\gamma$ siRNA for up to $30 \mathrm{~h}$ before exposing the cells to emodin $(50 \mu \mathrm{M})$ for an additional $24 \mathrm{~h}$. Afterwards, the expression of Sp1 and PPAR $\gamma$ protein was detected by Western blot. B, A549 and H1975 cells were transfected with control and Sp1 overexpression vectors for $24 \mathrm{~h}$ before exposing the cells to emodin for an additional $24 \mathrm{~h}$. Afterwards, Sp1, PPAR $\gamma$ and IGFBP1 protein expressions were determined using Western blot. C, Cellular protein was isolated from A549 cells transfected with control or PPAR $\gamma$ siRNA (50 nM), followed by control and Sp1 overexpression vectors for up to $30 \mathrm{~h}$ before exposing the cells to emodin $(50 \mu \mathrm{M})$ for an additional $24 \mathrm{~h}$. Afterwards, the expression of Sp1, PPAR $\gamma$ and IGFBP1 protein was detected by Western blot. *Indicates significant difference as compared to the untreated control group $(\mathrm{P}<0.05)$; ${ }^{* *}$ Indicates significance of combination treatment as compared with emodin plus control vector group $(\mathrm{P}<0.05)$. "Indicates significant difference as compared to the emodin plus Sp1 expression vector group ( $\mathrm{P}<0.05)$. D, A549 and H1975 cells were exposed to emodin and ciglitazone (30 $\mu \mathrm{M}$ ) for $24 \mathrm{~h}$, followed by measuring the protein expression of Sp1 by Western blot. The bar graphs represent the mean \pm SD of Sp1/PPAR/IGFBP1/GAPDH of three independent experiments. *Indicates significant difference as compared to the untreated control group $(\mathrm{P}<0.05)$; ${ }^{* *}$ Indicates significance of combination treatment as compared with emodin alone $(\mathrm{P}<0.05)$.

had no effect (not shown). As expected, a decreased protein expression of PCNA was observed in the emodin treated group as compared to that in the control one (Fig. 7D). 


\section{Cellular Physiology \\ Cell Physiol Biochem 2017;41:339-357 \\ and Biochemistry \begin{tabular}{l|l} 
DOI: 10.1159/000456281 2017 The Author(s). Published by S. Karger AG, Basel \\
\hline
\end{tabular}}

Tang et al.: Emodine Increases IGFBP1 Expression in Human Lung Cancer Cells

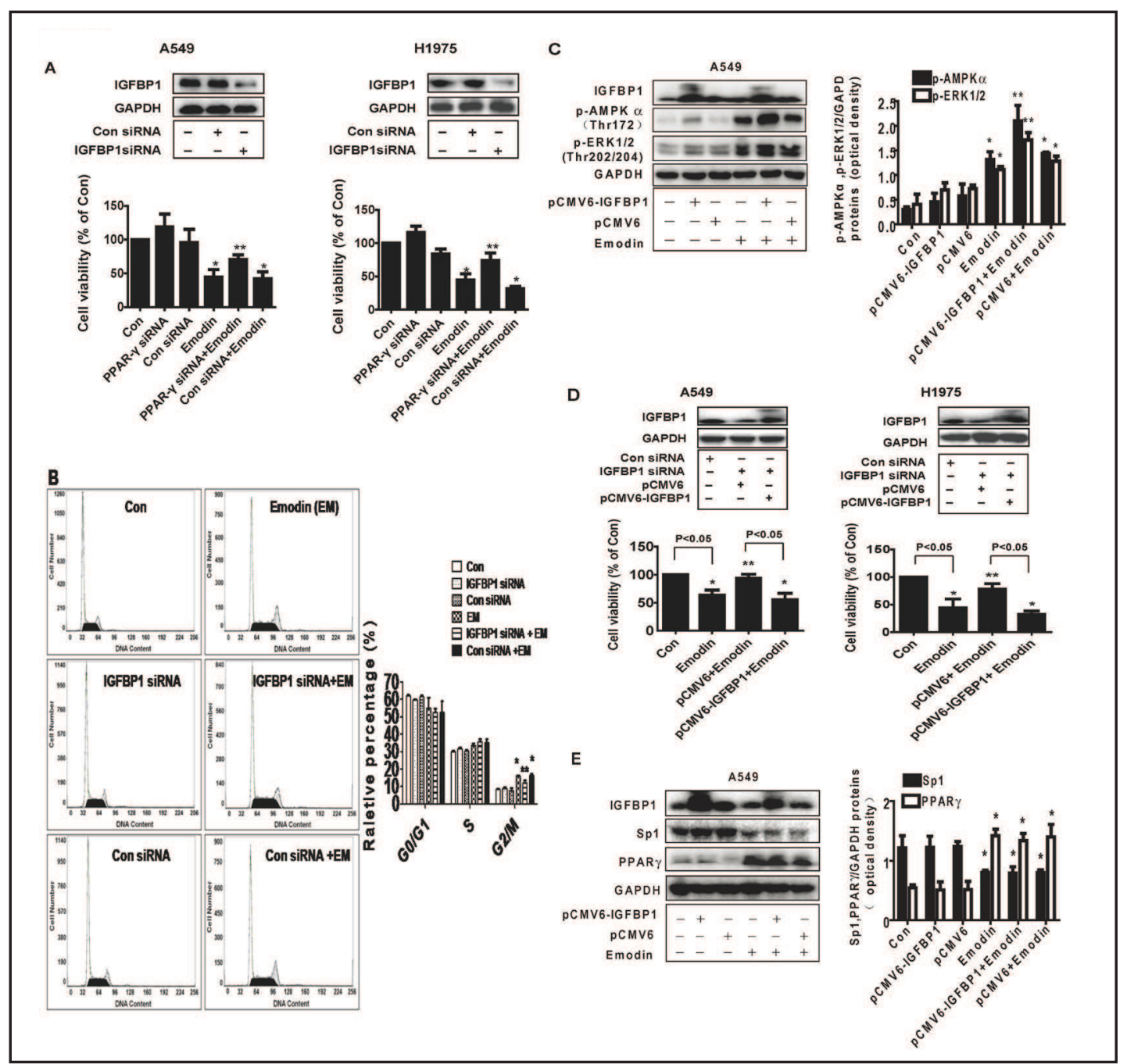

Fig. 6. Overexpression of IGFBP1 strengthened emodin-induced phosphorylation of ERK1/2 and AMPK $\alpha$, and restored growth inhibition in cells silencing of endogenous IGFBP1. A, A549 and H1975 cells were transfected with control or IGFBP1 siRNAs (50 nM each) for $24 \mathrm{~h}$ prior to exposure of the cells to emodin $(50 \mu \mathrm{M})$ for an additional $24 \mathrm{~h}$. Afterwards, IGFBP1 protein expressions and cell viability were determined by Western blot and MTT assays. Insert represents the protein expression of IFGBP-1. B, A549 cells were transfected control or IGFBP1 siRNA (50 $\mathrm{nM}$ ) for up to $30 \mathrm{~h}$ before exposing the cells to emodin (50 $\mu \mathrm{M})$ for an additional $24 \mathrm{~h}$. The cells were collected and processed for analysis of cell cycle distribution. Cell cycle was analyzed by flow cytometry after propidium iodide (PI) staining, and the percentages of the cell population in each phase (G0/G1, S and G2/M) of cell cycle were analyzed by Multicycle AV DNA Analysis Software. Data are expressed as a percentage of total cells. Values are given as the mean \pm SD, from 3 independent experiments. C, A549 cells were transfected with control (pCMV6) and IGFBP1 overexpression vectors for $24 \mathrm{~h}$ before exposing the cells to emodin $(50 \mu \mathrm{M})$ for an additional $2 \mathrm{~h}$ and $24 \mathrm{~h}$, respectively. Afterwards, phosphorylation of AMPK $\alpha$, ERK1/2 and IGFBP1 protein expressions were determined by Western blot. D, A549 and H1975 cells with silenced of IGFBP1 by siRNA previously were transfected with control and IGFBP1 overexpression vectors for $24 \mathrm{~h}$ before exposing the cells to emodin ( $50 \mu \mathrm{M})$ for an additional $24 \mathrm{~h}$. Afterwards, IGFBP1 protein expression and cell viability were determined using Western blot and MTT assays. E, A549 cells were transfected with control and IGFBP1 overexpression vectors for $24 \mathrm{~h}$ before exposing the cells to emodin $(50 \mu \mathrm{M})$ for an additional $24 \mathrm{~h}$. Afterwards, Sp1, PPAR $\gamma$ and IGFBP1 protein expressions were determined using Western blot. Values in bar graphs were given as the mean \pm SD from three independent experiments. *Indicates significant difference as compared to the untreated control group $(\mathrm{P}<0.05)$. **Indicates significant difference from emodin plus control vector group $(\mathrm{P}<0.01)$. 


\section{Cellular Physiology Cell Physiol Biochem 2017;41:339-357

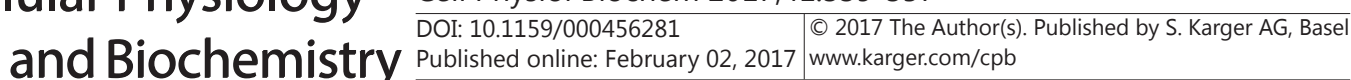

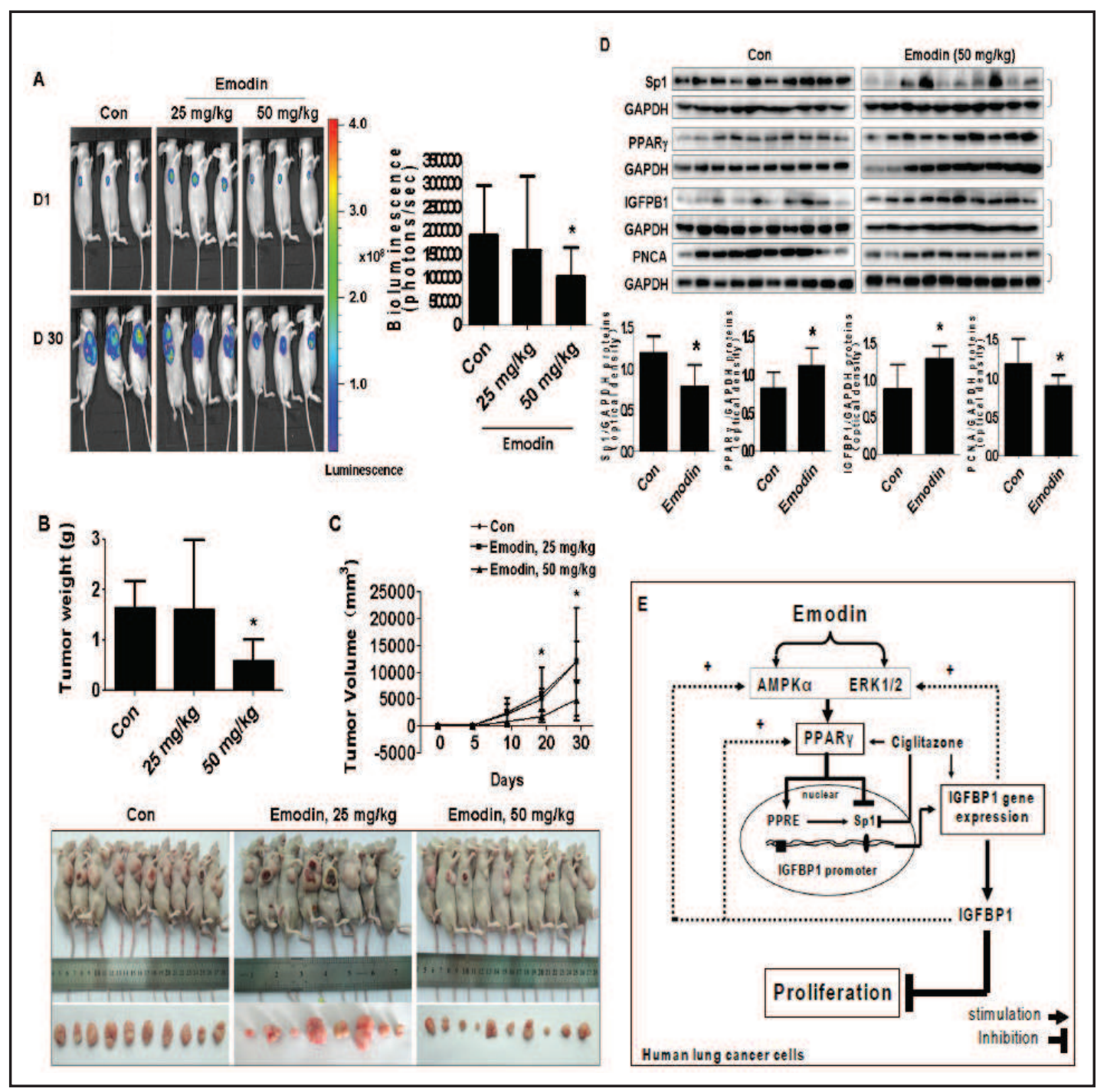

Fig. 7. In vivo anti-tumor efficacy of emodin in subcutaneous xenograft models of lung cancer. Mice ( $\mathrm{n}=8$ 10/group) were divided to 3 groups [Con (saline), Low (L, $25 \mathrm{mg} / \mathrm{kg}$ ) and High (H, $50 \mathrm{mg} / \mathrm{kg}$ )], and emodin was given at the $10^{\text {th }}$ day after tumor cells injection by intraperitoneal injection (once another day) for up to 30 days. A, The xenografts were assessed by in vivo bioluminescence imaging at the first and end of the experiments (on day 1 and 30). The tumor growth was monitored by injecting luciferin in the mice followed by measuring bioluminescence using IVIS Imaging System. Imaging and quantification of signals were controlled by the acquisition and analysis software living image as described in the Materials and Methods section. Representative images are shown. B and C, The xenografts were harvested on day 30, and the volume and weight of tumors were measured. D, At the end of the experiments, xenograft tumors were isolated from individual animals and the corresponding lysates were immunoblotted for detecting IGFBP1, Sp1 and PPAR $\gamma$, and PNCA by Western blot with the indicated antibodies. GAPDH was used as loading control. The bar graphs represented the tumor weight and volume of mice results of as mean \pm SD. *Indicates the significant difference from untreated control $(\mathrm{p}<0.05)$. E, The diagram shows that emodin inhibits growth of NSCLC cells through activation of PPAR $\gamma$, which is dependent upon activation of AMPK $\alpha$ and ERK1/2 signaling pathways, followed by reduction of Sp1 expression, this in turn leads to induce the expression of IGFBP1. Overexpression of IGFBP1 feedback increases emodin-induced phosphorylation of AMPK $\alpha$ and ERK1/2, and PPAR $\gamma$ expression. In addition, ciglitazone enhances the overall effects of emodin. The complex signaling networks, positive feedback regulatory loops, and cooperative interactions between transcription factors (e.g., PPAR $\gamma$ and Sp1) contribute to the overall responses of emodin.

\section{KARGER}




\section{Cellular Physiology Cell Physiol Biochem 2017;41:339-357

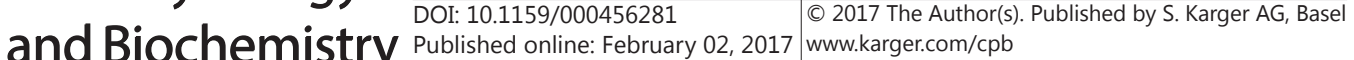

Tang et al.: Emodine Increases IGFBP1 Expression in Human Lung Cancer Cells

\section{Discussion}

Growing interest has focused on the use of natural herbs or plants to reduce the incidence and mortality of cancer, leading to encouraging results. Emodin, a bioactive anthraquinone derivative isolated from the rhizomes of Rheum palmatum, has been reported to have various pharmacological functions including anti-cancer activities. Overall, our studies further confirmed the anti-cancer effects of emodin and suggested that this agent can be used as potential therapeutic modality in several cancers $[32,33]$. Although there were important discoveries revealed by previous studies indicated potential multiple signaling pathways and molecular genes or proteins that had been involved in the anti-tumor responses and other functions of emodin $[8,10,34]$, the detailed molecular mechanisms by which this agent in anti-cancer effects still remained to be elucidated. Consistent with our previous study [11], we observed that emodin induced cell cycle arrest in G2/M phase checkpoint and reduced migration and invasion in lung cancer cells, which was in line with its widely established anti-tumor role of emodin [8-10,35] implying the possibility of inhibition of both mitotic division and DNA replications which finally reduces cell division rates by emodin in this process. Thus, further testing the cell cycle related signaling pathways and proteins, such as cyclins, cyclin-dependent kinase inhibitors, p27/p21, and the detailed links of those molecules described above contributing to lung cancer cell growth inhibition are needed in the future.

Interestingly, we found that increased expression of PPAR $\gamma$, one of the ligand-dependent nuclear transcription factors, stimulated the emodin-inhibited cell proliferation. Emodin was shown to activate PPRE luciferase activity. Activation of PPAR $\gamma$ by its known ligands showed various functions including growth inhibition, induction of apoptosis and inflammatory responsiveness in several other cell types [7,36,37]. Our results suggested that emodin may be considered as one of novel PPAR $\gamma$ ligands although more experiments were needed to confirm this. Consistent with this, activation and/or induced expression of PPAR $\gamma$ by emodin were shown in other studies $[38,39]$. One study found that emodin, by activation of PPAR $\gamma$, affecting lipopolysaccharide (LPS)-induced multiple signaling pathways, thereby reducing LPS-induced inflammatory effects in mouse mammary epithelial cells [38].

Several studies demonstrated that the multiple pathways and different molecular targets have been involved in the emodin-inhibited cancer cell growth $[8,11,40]$. While limited and inconsistent data showed the activation of MEK/ERK and AMPK kinase signaling in the regulation of PPAR $\gamma$ expression [41, 42], our results suggested the important roles of MEK/ERK and AMPK $\alpha$ activation, which were required to stimulate emodin-induced activation and induction of PPAR $\gamma$. The involvement of these kinase in not only emodininduced biological functions, such as cancer cell growth inhibition, but also PPAR $\gamma$ signalinginduced responses have been shown in other studies [8, 38, 39, 43], suggesting the critical role of these two signaling pathways in influencing the effect of emodin. It also indicated the upstream signals of PPAR $\gamma$ in this process.

Furthermore, we demonstrated a potential feedback regulation of AMPK $\alpha$ and ERK1/2 by IGFBP1, one of the PPAR targets [24]. The links of AMPK $\alpha$, ERK1/2 signaling to IGFBP1 expression/function have been reported [44, 45]; early study found that a pro-inflammatory cytokine IL-1 $\beta$ stimulated IGFBP1 synthesis through activation of MEK/ERK signaling in human hepatoma cells [44]. Also, report showed that activation of AMPK could stimulate IGFBP1 secretion, thereby overcoming the inhibitory effect of insulin in rat hepatoma cells [46]. While our results implicated a positive feedback regulatory loop of AMPK $\alpha$ signaling, the possible involvement of other kinase signaling pathways, and up- or downstream mediators underlying this regulation, such as phosphorylation and regulation of IGF-1 receptor $[47,48]$, regulation of IGFs [49], forkhead box class O (FOXO) [50], and hypoxia-inducible factor (HIF) [51], among others, required to be elucidated in the future studies. In addition to inhibiting IGF effects [52], IGFBP1 also showed to suppress cancer cell proliferation, invasiveness and motility via stimulating or inhibiting several critical downstream genes and/or proteins [51, 53], which highlighted a tumor suppressor role of IGFBP1. Consistent with these, our results 


\section{Cellular Physiology Cell Physiol Biochem 2017;41:339-357 and Biochemistry Publisned online: February 02, 2017 www.karger.com/cpb}

Tang et al.: Emodine Increases IGFBP1 Expression in Human Lung Cancer Cells

implied that the induction of IGFBP1 expression was required in stimulating the emodininhibited NSCLC growth. However, increased IGFBP1 appeared to be associated with shorter overall survival in men with advanced prostate cancer [23]. Thus, the true functions of IGFBP1 representing a tumor suppressor or oncogene may depend on the capacity of content and environment exposed, which required to be determined. Nevertheless, our study suggested that IGFBP1 may be considered as potential biomarker for lung cancer progression, and that increased IGFBP1 could add compatible with current treatment regimes for lung cancer.

We demonstrated an important role of Sp1 in mediating the effect of emodin on IGFBP1 expression. As a common ubiquitous transcription factor that binds to GC-rich motifs of gene promoters, Sp1, with the ability to function as an oncogene or a tumor suppressor depending on the environmental context, was involved in many cellular functions, including differentiation, growth, and apoptosis through regulation of several target genes [54]. One study demonstrated that Sp1-like binding site was responsible for the activation of IGFBP1 gene promoter in human endometrial stromal cells [31]. Interestingly, our findings suggested that reduction of Sp1 led to upregulation of IGFBP1 expression by emodin. As the true role of IGFBP1 on lung cancer occurrence and progression have not been well elucidated. It is possible that other intermediates (genes/proteins with or without binding to IGFBP1 promoter) may be involved in the process. Therefore, the potential pathways and mechanisms underlying the reduced-Sp1 protein leading to increase in IGFBP1 expression still remained to be determined with more in depth experiments in the future. Moreover, our additional data implied that the expression of PPAR $\gamma$ was required to correlate with Sp1 in influencing emodin-induced IGFBP1 expression. Also, there is a positive feedback regulatory axis between PPAR $\gamma$ and IGFBP1. Thus, the complicated signaling networks and interactions between transcription factors (e.g., PPAR $\gamma$ and Sp1) may control the expression of IGFBP1, this, together with the positive regulatory loop, converged on the overall response of emodin. The interplay of PPAR $\gamma$ and Sp1 was reported in other studies. One study showed that PPAR $\gamma$ mediated the anti-proliferative effect of cladosporol A, a secondary metabolite from cladosporium tenuissimum, through interacting with Sp1, followed by stimulating expression of cyclin-dependent kinase p21 (Waf1/Cip1) in colorectal cancer cells [55]. Also, the interaction between Sp1 and PPAR $\gamma$ along, or with other transcription factors, such as CCAAT enhancer binding protein alpha (C/EBP-alpha), activating transcription factor 2 (ATF2) and activator protein 1 (AP-1), could trigger the expression of resistin gene in human monocytic cells [56]. Moreover, one report demonstrated that reduction of Sp1 mediated the anti-tumor effect of emodin and other extracts of polygonum cuspidatum root in oral cancer cells via inhibiting survivin, one of downstream targets of Sp1 [57]. Nevertheless, more experiments are required to determine if there is a physical binding between Sp1 and PPAR $\gamma$ that might influence emodin-induced IGFBP1 expression and its downstream responses.

Of note, we showed that both PPAR $\gamma$ and IGFBP1 expression were involved in the emodininhibited cell proliferation and -induced cell cycle arrest; although our results suggested that PPAR $\gamma$ may be upstream ofIGFBP1 in this process, whether these two signaling pathways (PPAR and IGFBP1) were activated in parallel by emodin, and how they directly converge on emodin-inhibited lung cancer cell growth still remained to be determined.

We previously showed that the cross-talk of AMPK $\alpha$ and MEK/ERK signaling and the reciprocal interaction between Sp1 and c-Jun proteins contribute to the emodin-inhibited the expression of ILK, which was important in mediating emodin-induced inhibition of lung cancer cell growth [11]. Given the fact that emodin inhibited cancer cell growth through mechanisms in which regulating multiple signaling pathways and targeting genes/proteins have been shown in the past, our findings implied that emodin inhibited lung cancer growth through not only inhibition of ILK but also induction of IGFBP1 gene expression via AMPK $\alpha$ and MEK/ERK-mediated regulation of transcription factors Sp1, c-Jun and PPAR $\gamma$. Whether there is a parallel or up-downstream signaling pathway, or potential cross-talk involving in the effect of emodin and which targets (e.g., ILK and IGFBP1 genes) plays a major role required to be determined with more experimental approaches. 


\section{Cellular Physiology Cell Physiol Biochem 2017;41:339-357 and Biochemistry Published online: February 02, 2017 www.karger.com/cpb}

Tang et al.: Emodine Increases IGFBP1 Expression in Human Lung Cancer Cells

Alternatively, our results also suggested the possibility of a synergy of emodin and ciglitazone, the enhanced anti-tumor effects of combined emodin and agents, such as curcumin, other than PPAR $\gamma$ ligands with distinct mechanisms involved were reported in several cancer types $[40,58]$. Thus, future iterations of this combination may in fact unveiled even greater potency and offered a new strategy in controlling lung cancer growth with less adverse effects. However, more detailed studies are needed to identify insight into the mechanism of synergy between ciglitazone and emodin.

More importantly, our in vivo data were consistent with the findings from that in vitro, confirming the effect of emodin on lung cancer growth inhibition and regulation of IGFBP1, Sp1 and PPAR $\gamma$ expressions. The given doses of emodin were similar with others demonstrating the significant effects in the inhibition of other cancer types [30,59]. More experiments are required to further determine the critical role of IGFBP1 in this process using cells stable transfected with shRNA and exogenously expression vector of IGFBP1 in nude mice model. Of note, emodin has been shown to inhibit tumor metastasis in vivo in other studies $[30,60]$. Whether emodin has potential in inhibition of metastasis in lung xenograft tumors required to be determined.

In summary, our results show that emodin inhibits growth of NSCLC cells through activation of PPAR $\gamma$, which is dependent upon activation of AMPK $\alpha$ and MEK/ ERK signaling pathways, followed by reduction of $\mathrm{Sp} 1$, this leads to induce the expression of IGFBP1 gene. There is a synergy of emodin and ciglitazone. Intriguingly, the interactions between $\operatorname{PPAR} \gamma$ and $\mathrm{Sp} 1$ are required in regulating IGFBP1 expression. Moreover, exogenously expression of IGFBP1 positively feedback strengthens emodin-induced phosphorylation of AMPK $\alpha$, ERK1/2, and PPAR expression. Thus, the complex signaling cascades, positive feedback regulatory loops, and cooperative interplay of transcription factors (e.g., PPAR $\gamma$ and Sp1)-induced expression of IGFBP1 contribute to the overall responses of emodin (Fig. 7E). This study unveils a novel mechanism by which emodin inhibits growth of human lung cancer cells. Despite the strong preclinical evidence of positive anti-tumor effects, studies to date have not confirmed the benefits of emodin in humans. Potential efficacy, safety profiles, bioavailability and pharmacokinetic studies of emodin are all required in human subjects. Thus, the clinical significance of emodin deserves further investigation in human studies

\section{Acknowledgments}

We are grateful to Dr. Bruce M. Spiegelman (Dana-Farber Cancer Institute, Harvard Medical School, Massachusetts, USA) for providing PPRE X3-Tk-luc reporter. Dr. Thomas E Eling (NIEHS, USA) for providing the Sp1 expression vectors. This work was supported in part by the Specific Science and Technology Research Fund from Guangdong Provincial Hospital of Chinese Medicine (Grant No YK2013B2N13, YN2015MS19), the Science and Technology Program of Guangzhou (Grant No 20150429090456547), the Special Science and Technology Join fund from Guangdong Provincial Department of Science and Technology-Guangdong Academy of Traditional Chinese Medicine (Grant No 2012A032500011, 2014A020221024) and grants from the National Nature Scientific Foundation of China (Grant No 81272614, 81403216).

\section{Disclosure Statement}

The authors declare that they have no competing interests. 


\section{Cellular Physiology \\ Cell Physiol Biochem 2017;41:339-357 and Biochemistry

\section{References}

$\rightarrow 1$ Siegel RL, Miller KD, Jemal A: Cancer statistics, 2015. CA Cancer J Clin 2015;65:5-29.

-2 Chang GC, Chen KC, Yang TY, Yin MC, Lin CP, Kuo BI, Hsu JY: Activity of gefitinib in advanced non-small-cell lung cancer with very poor performance status. Invest New Drugs 2005;23:73-77.

3 Lehrke M, Lazar MA: The many faces of ppargamma. Cell 2005;123:993-999.

4 Giaginis C, Politi E, Alexandrou P, Sfiniadakis J, Kouraklis G, Theocharis S: Expression of peroxisome proliferator activated receptor-gamma (ppar-gamma) in human non-small cell lung carcinoma: Correlation with clinicopathological parameters, proliferation and apoptosis related molecules and patients' survival. Pathol Oncol Res 2012;18:875-883.

5 Elstner E, Muller C, Koshizuka K, Williamson EA, Park D, Asou H, Shintaku P, Said JW, Heber D, Koeffler HP: Ligands for peroxisome proliferator-activated receptorgamma and retinoic acid receptor inhibit growth and induce apoptosis of human breast cancer cells in vitro and in bnx mice. Proc Natl Acad Sci U S A 1998;95:8806-8811.

6 Shen B, Chu ES, Zhao G, Man K, Wu CW, Cheng JT, Li G, Nie Y, Lo CM, Teoh N, Farrell GC, Sung JJ, Yu J: Ppargamma inhibits hepatocellular carcinoma metastases in vitro and in mice. Br J Cancer 2012;106:14861494.

7 Cao LQ, Shao ZL, Liang HH, Zhang DW, Yang XW, Jiang XF, Xue P: Activation of peroxisome proliferatoractivated receptor-gamma (ppargamma) inhibits hepatoma cell growth via downregulation of sept2 expression. Cancer Lett 2015;359:127-135.

8 Shrimali D, Shanmugam MK, Kumar AP, Zhang J, Tan BK, Ahn KS, Sethi G: Targeted abrogation of diverse signal transduction cascades by emodin for the treatment of inflammatory disorders and cancer. Cancer Lett 2013;341:139-149.

9 Thimmegowda NR, Park C, Shwetha B, Sakchaisri K, Liu K, Hwang J, Lee S, Jeong SJ, Soung NK, Jang JH, Ryoo IJ, Ahn JS, Erikson RL, Kim BY: Synthesis and antitumor activity of natural compound aloe emodin derivatives. Chem Biol Drug Des 2015;85:638-644.

10 Jia X, Yu F, Wang J, Iwanowycz S, Saaoud F, Wang Y, Hu J, Wang Q Fan D: Emodin suppresses pulmonary metastasis of breast cancer accompanied with decreased macrophage recruitment and $\mathrm{m} 2$ polarization in the lungs. Breast Cancer Res Treat 2014;148:291-302.

11 Tang Q, Zhao S, Wu J, Zheng F, Yang L, Hu J, Hann SS: Inhibition of integrin-linked kinase expression by emodin through crosstalk of ampkalpha and erk1/2 signaling and reciprocal interplay of sp1 and c-jun. Cell Signal 2015;27:1469-1477.

12 Ko JC, Su YJ, Lin ST, Jhan JY, Ciou SC, Cheng CM, Chiu YF, Kuo YH, Tsai MS, Lin YW: Emodin enhances cisplatin-induced cytotoxicity via down-regulation of ercc1 and inactivation of erk1/2. Lung Cancer 2010;69:155-164.

13 Major JM, Laughlin GA, Kritz-Silverstein D, Wingard DL, Barrett-Connor E: Insulin-like growth factor-i and cancer mortality in older men. J Clin Endocrinol Metab 2010;95:1054-1059.

14 Baxter RC: Igf binding proteins in cancer: Mechanistic and clinical insights. Nat Rev Cancer 2014;14:329341.

15 Kubota T, Kamada S, Taguchi M, Aso T: Determination of insulin-like growth factor-2 in feto-maternal circulation during human pregnancy. Acta Endocrinol (Copenh) 1992;127:359-365.

16 Chevallier B, Lagarde A, Degrelle H, Belaisch-Allart J, Giraudet P, Gallet JP: Insulin-like growth factor binding protein 1 level in amniotic fluid: Correlation with birth weight. Biol Neonate 1998;73:404-406.

-17 Ammoun S, Schmid MC, Zhou L, Ristic N, Ercolano E, Hilton DA, Perks CM, Hanemann CO: Insulin-like growth factor-binding protein-1 (igfbp-1) regulates human schwannoma proliferation, adhesion and survival. Oncogene 2012;31:1710-1722.

-18 Nijaguna MB, Patil V, Urbach S, Shwetha SD, Sravani K, Hegde AS, Chandramouli BA, Arivazhagan A, Marin P, Santosh V, Somasundaram K: Glioblastoma-derived macrophage colony-stimulating factor (mcsf) induces microglial release of insulin-like growth factor-binding protein 1 (igfbp1) to promote angiogenesis. J Biol Chem 2015;290:23401-23415.

-19 Figueroa JA, Sharma J, Jackson JG, McDermott MJ, Hilsenbeck SG, Yee D: Recombinant insulin-like growth factor binding protein-1 inhibits igf-i, serum, and estrogen-dependent growth of mcf-7 human breast cancer cells. J Cell Physiol 1993;157:229-236. 


\section{Cellular Physiology \\ Cell Physiol Biochem 2017;41:339-357 and Biochemistry

20 Van den Berg CL, Cox GN, Stroh CA, Hilsenbeck SG, Weng CN, McDermott MJ, Pratt D, Osborne CK, Coronado-Heinsohn EB, Yee D: Polyethylene glycol conjugated insulin-like growth factor binding protein-1 (igfbp-1) inhibits growth of breast cancer in athymic mice. Eur J Cancer 1997;33:1108-1113.

-21 Yamada H, Iijima K, Tomita O, Taguchi T, Miharu M, Kobayashi K, Okita H, Saito M, Shimizu T, Kiyokawa $\mathrm{N}$ : Effects of insulin-like growth factor-1 on b-cell precursor acute lymphoblastic leukemia. Int J Hematol 2013;97:73-82.

-22 Cao Y, Nimptsch K, Shui IM, Platz EA, Wu K, Pollak MN, Kenfield SA, Stampfer MJ, Giovannucci EL: Prediagnostic plasma igfbp-1, igf-1 and risk of prostate cancer. Int J Cancer 2015;136:2418-2426.

-23 Sharma J, Gray KP, Evan C, Nakabayashi M, Fichorova R, Rider J, Mucci L, Kantoff PW, Sweeney CJ: Elevated insulin-like growth factor binding protein-1 (igfbp-1) in men with metastatic prostate cancer starting androgen deprivation therapy (adt) is associated with shorter time to castration resistance and overall survival. Prostate 2014;74:225-234.

-24 Degenhardt T, Matilainen M, Herzig KH, Dunlop TW, Carlberg C: The insulin-like growth factorbinding protein 1 gene is a primary target of peroxisome proliferator-activated receptors. J Biol Chem 2006;281:39607-39619.

25 Zheng F, Tang Q, Wu J, Zhao S, Liang Z, Li L, Wu W, Hann S: P38alpha mapk-mediated induction and interaction of foxo3a and p53 contribute to the inhibited-growth and induced-apoptosis of human lung adenocarcinoma cells by berberine. J Exp Clin Cancer Res 2014;33:36.

-26 Zhao S, Wu J, Zheng F, Tang Q Yang L, Li L, Wu W, Hann SS: Beta-elemene inhibited expression of DNA methyltransferase 1 through activation of erk $1 / 2$ and ampkalpha signalling pathways in human lung cancer cells: The role of sp1. J Cell Mol Med 2015;19:630-641.

27 Hann SS, Chen J, Wang Z, Wu J, Zheng F, Zhao S: Targeting ep4 by curcumin through cross talks of ampdependent kinase alpha and p38 mitogen-activated protein kinase signaling: The role of pgc-1alpha and sp1. Cell Signal 2013;25:2566-2574.

-28 Kim JB, Wright HM, Wright M, Spiegelman BM: Add1/srebp1 activates ppargamma through the production of endogenous ligand. Proc Natl Acad Sci U S A 1998;95:4333-4337.

-29 Kambe A, Iguchi G, Moon Y, Kamitani H, Watanabe T, Eling TE: Regulation of ep4 expression via the sp-1 transcription factor: Inhibition of expression by anti-cancer agents. Biochim Biophys Acta 2008;1783:1211-1219.

-30 Subramaniam A, Shanmugam MK, Ong TH, Li F, Perumal E, Chen L, Vali S, Abbasi T, Kapoor S, Ahn KS, Kumar AP, Hui KM, Sethi G: Emodin inhibits growth and induces apoptosis in an orthotopic hepatocellular carcinoma model by blocking activation of stat3. Br J Pharmacol 2013;170:807-821.

-31 Gao JG, Mazella J, Tseng L: Activation of the human igfbp-1 gene promoter by progestin and relaxin in primary culture of human endometrial stromal cells. Mol Cell Endocrinol 1994;104:39-46.

-32 Xie MJ, Ma YH, Miao L, Wang Y, Wang HZ, Xing YY, Xi T, Lu YY: Emodin-provoked oxidative stress induces apoptosis in human colon cancer hct116 cells through a p53-mitochondrial apoptotic pathway. Asian Pac J Cancer Prev 2014;15:5201-5205.

33 Way TD, Huang JT, Chou CH, Huang CH, Yang MH, Ho CT: Emodin represses twist1-induced epithelialmesenchymal transitions in head and neck squamous cell carcinoma cells by inhibiting the beta-catenin and akt pathways. Eur J Cancer 2014;50:366-378.

-34 Mischitelli M, Jemaa M, Almasry M, Faggio C, Lang F: Triggering of erythrocyte cell membrane scrambling by emodin. Cell Physiol Biochem 2016;40:91-103.

-35 Rauchfuss F, Lambeck S, Claus RA, Ullmann J, Schulz T, Weber M, Katenkamp K, Guthke R, Bauer M, Settmacher U: Sustained liver regeneration after portal vein embolization --a human molecular pilot study. Dig Liver Dis 2012;44:681-688.

-36 Abduljabbar R, Al-Kaabi MM, Negm OH, Jerjees D, Muftah AA, Mukherjee A, Lai CF, Buluwela L, Ali S, Tighe PJ, Green A, Ellis I, Rakha E: Prognostic and biological significance of peroxisome proliferator-activated receptor-gamma in luminal breast cancer. Breast Cancer Res Treat 2015;150:511-522.

-37 Yang D, Chen H, Zeng X, Xie P, Wang X, Liu C: Macrophage cgi-58 attenuates inflammatory responsiveness via promotion of ppargamma signaling. Cell Physiol Biochem 2016;38:696-713.

-38 Yang Z, Zhou E, Wei D, Li D, Wei Z, Zhang W, Zhang X: Emodin inhibits lps-induced inflammatory response by activating ppar-gamma in mouse mammary epithelial cells. Int Immunopharmacol 2014;21:354-360.

-39 Chen Z, Zhang L, Yi J, Yang Z, Zhang Z, Li Z: Promotion of adiponectin multimerization by emodin: A novel ampk activator with ppargamma-agonist activity. J Cell Biochem 2012;113:3547-3558. 


\section{Cellular Physiology \\ Cell Physiol Biochem 2017;41:339-357 and Biochemistry

40 Thacker PC, Karunagaran D: Curcumin and emodin down-regulate tgf-beta signaling pathway in human cervical cancer cells. PLoS One 2015;10:e0120045.

-41 Bhatt KH, Sodhi A, Chakraborty R: Peptidoglycan induced expression of peroxisome proliferatoractivated receptor gamma in mouse peritoneal macrophages: Role of erk and jnk map kinases. Cytokine 2012;60:778-786.

42 Sozio MS, Lu C, Zeng Y, Liangpunsakul S, Crabb DW: Activated ampk inhibits ppar-\{alpha\} and ppar-\{gamma\} transcriptional activity in hepatoma cells. Am J Physiol Gastrointest Liver Physiol 2011;301:G739-747.

43 Chen TJ, Zhou YF, Ning JJ, Yang T, Ren H, Li Y, Zhang S, Chen MW: Nbm-t-bmx-os01, an osthole derivative, sensitizes human lung cancer a549 cells to cisplatin through ampk-dependent inhibition of erk and akt pathway. Cell Physiol Biochem 2015;36:893-906.

-44 Frost RA, Nystrom GJ, Lang CH: Stimulation of insulin-like growth factor binding protein-1 synthesis by interleukin-1beta: Requirement of the mitogen-activated protein kinase pathway. Endocrinology 2000;141:3156-3164.

45 Laskov I, Drudi L, Beauchamp MC, Yasmeen A, Ferenczy A, Pollak M, Gotlieb WH: Anti-diabetic doses of metformin decrease proliferation markers in tumors of patients with endometrial cancer. Gynecol Oncol 2014;134:607-614.

-46 Lewitt MS: Stimulation of igf-binding protein-1 secretion by amp-activated protein kinase. Biochem Biophys Res Commun 2001;282:1126-1131.

47 Yee D, Jackson JG, Kozelsky TW, Figueroa JA: Insulin-like growth factor binding protein 1 expression inhibits insulin-like growth factor i action in mcf-7 breast cancer cells. Cell Growth Differ 1994;5:73-77.

48 Tian Z, Yao G, Song H, Zhou Y, Geng J: Igf2r expression is associated with the chemotherapy response and prognosis of patients with advanced nsclc. Cell Physiol Biochem 2014;34:1578-1588.

49 Wang J, Razuvaev A, Folkersen L, Hedin E, Roy J, Brismar K, Hedin U: The expression of igfs and igf binding proteins in human carotid atherosclerosis, and the possible role of igf binding protein-1 in the regulation of smooth muscle cell proliferation. Atherosclerosis 2012;220:102-109.

-50 Grinius L, Kessler C, Schroeder J, Handwerger S: Forkhead transcription factor foxo1a is critical for induction of human decidualization. J Endocrinol 2006;189:179-187.

51 Geis T, Popp R, Hu J, Fleming I, Henke N, Dehne N, Brune B: Hif-2alpha attenuates lymphangiogenesis by up-regulating igfbp1 in hepatocellular carcinoma. Biol Cell 2015;107:175-188.

52 Park JH, Rasch MG, Qiu J, Lund IK, Egeblad M: Presence of insulin-like growth factor binding proteins correlates with tumor-promoting effects of matrix metalloproteinase 9 in breast cancer. Neoplasia 2015;17:421-433.

-53 Zhang X, Yee D: Insulin-like growth factor binding protein-1 (igfbp-1) inhibits breast cancer cell motility. Cancer Res 2002;62:4369-4375.

54 Beishline K, Azizkhan-Clifford J: Sp1 and the 'hallmarks of cancer'. FEBS J 2015;282:224-258.

55 Zurlo D, Assante G, Moricca S, Colantuoni V, Lupo A: Cladosporol a, a new peroxisome proliferator-activated receptor gamma (ppargamma) ligand, inhibits colorectal cancer cells proliferation through beta-catenin/ tcf pathway inactivation. Biochim Biophys Acta 2014;1840:2361-2372.

56 Singh AK, Battu A, Mohareer K, Hasnain SE, Ehtesham NZ: Transcription of human resistin gene involves an interaction of sp1 with peroxisome proliferator-activating receptor gamma (ppargamma). PLoS One 2010;5:e9912.

-57 Shin JA, Shim JH, Jeon JG, Choi KH, Choi ES, Cho NP, Cho SD: Apoptotic effect of polygonum cuspidatum in oral cancer cells through the regulation of specificity protein 1. Oral Dis 2011;17:162-170.

58 Guo J, Li W, Shi H, Xie X, Li L, Tang H, Wu M, Kong Y, Yang L, Gao J, Liu P, Wei W: Synergistic effects of curcumin with emodin against the proliferation and invasion of breast cancer cells through upregulation of mir-34a. Mol Cell Biochem 2013;382:103-111.

-59 Ma J, Yang J, Wang C, Zhang N, Dong Y, Wang Y, Lin X: Emodin augments cisplatin cytotoxicity in platinumresistant ovarian cancer cells via ros-dependent mrp1 downregulation. Biomed Res Int 2014;2014:107671.

-60 Sun Y, Wang X, Zhou Q Lu Y, Zhang H, Chen Q, Zhao M, Su S: Inhibitory effect of emodin on migration, invasion and metastasis of human breast cancer mda-mb-231 cells in vitro and in vivo. Oncol Rep 2015;33:338-346. 